\title{
وعى الريفيين بأضرار التعدى على المجارى المائية بقريتين بمحافظة البحيرة
}

\author{
أمانى سعيد عبد الحميد الخولى الزئى \\ قسم بحوث المجتمع الريفى، معهد بحوث الإرشاد الزراعى والتيل التمية الريفية، مركز البحوث الزر اعية
}

Received: Jul. 25, 2017

Accepted: Aug. 6, 2017

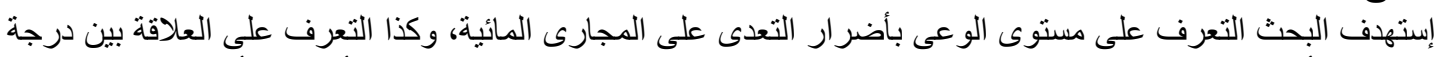

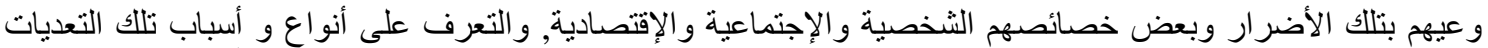

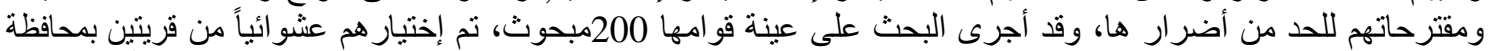

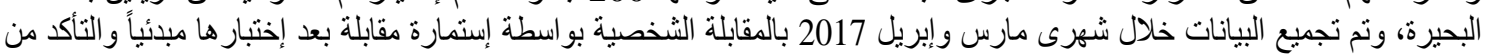

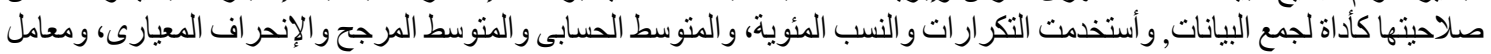

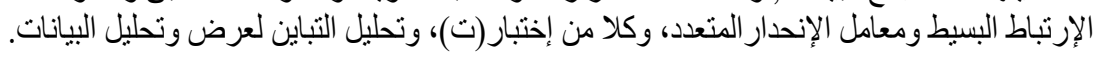

وقد توصل البحث إلى النتائج الآتية:

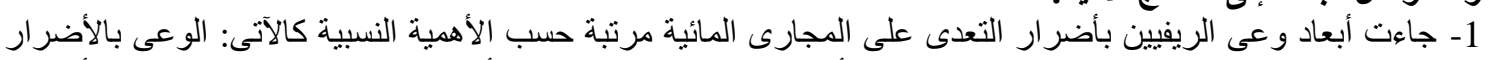

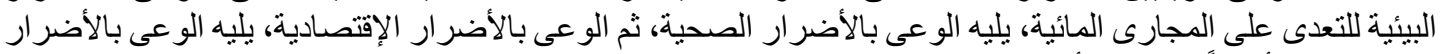

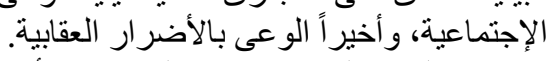

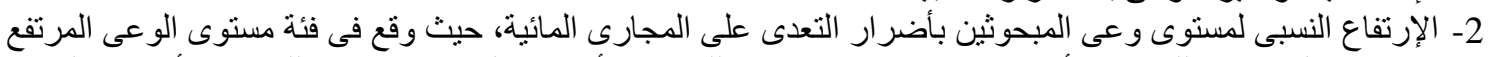

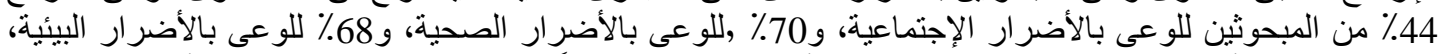

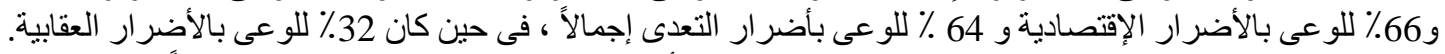

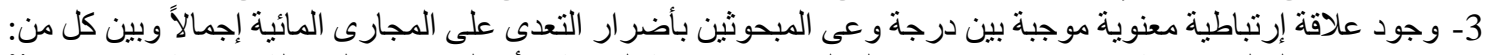

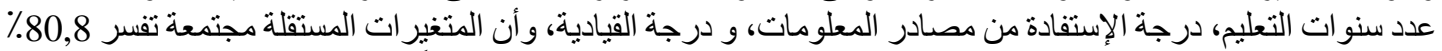

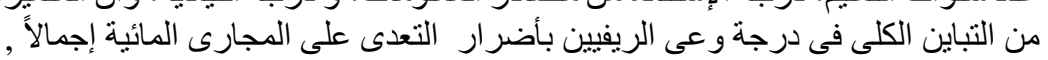

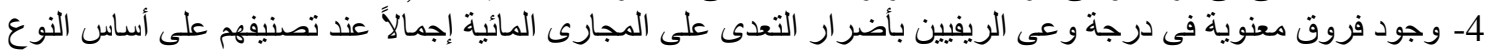

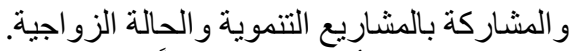

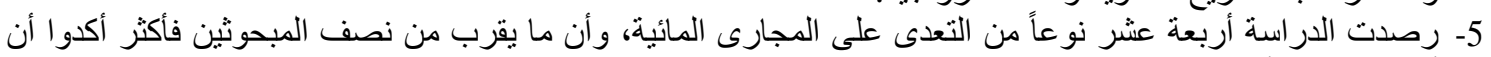

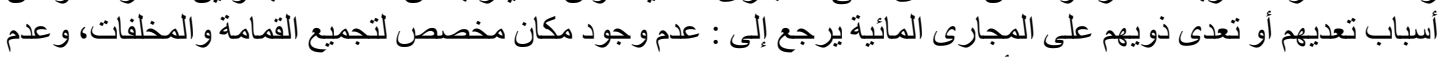

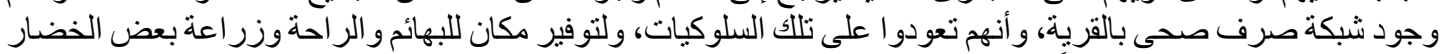

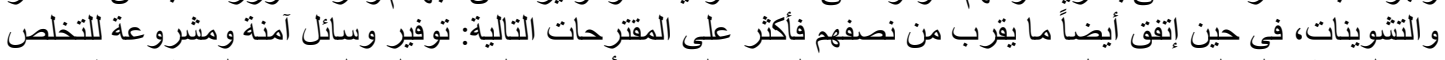

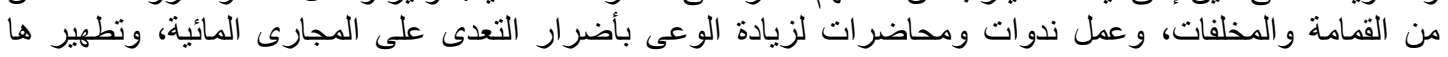

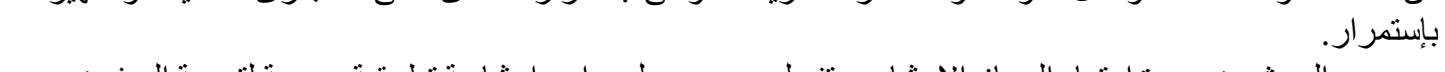

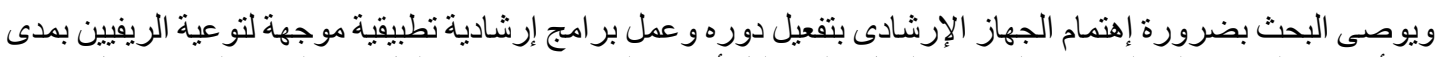

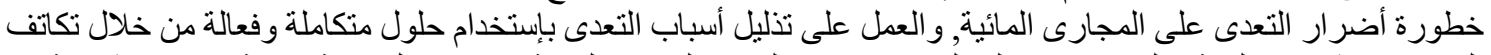

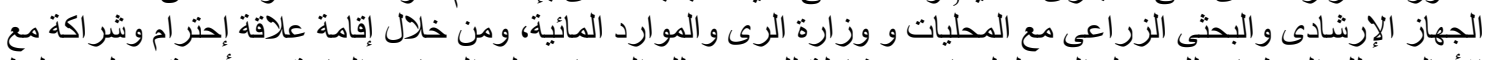

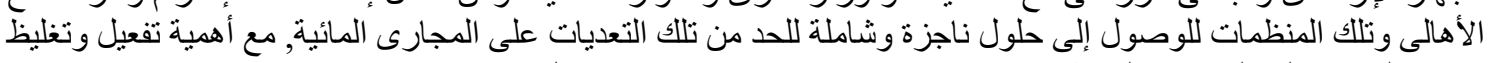

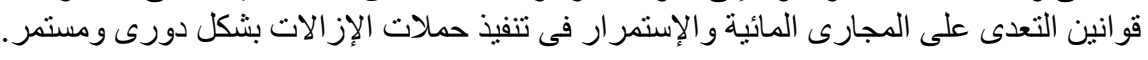

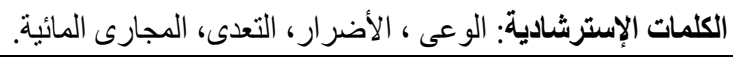

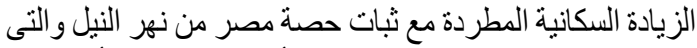

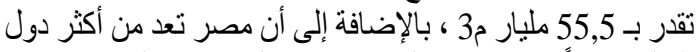

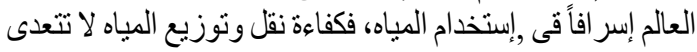

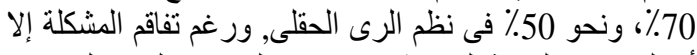

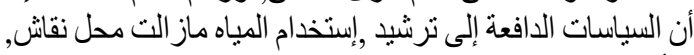

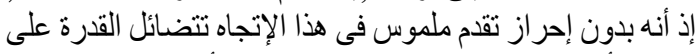

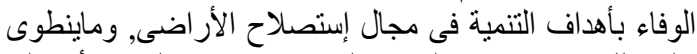

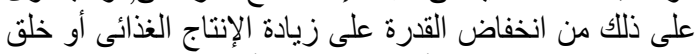

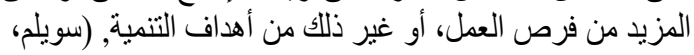

. (2015

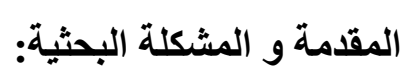

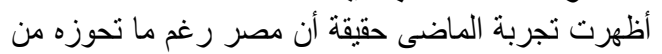

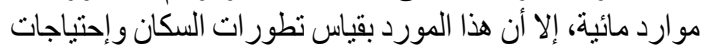

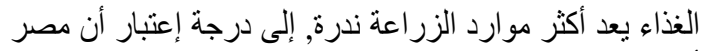

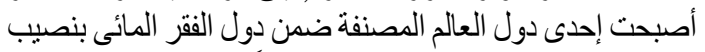

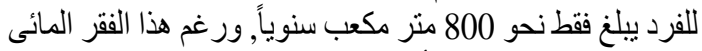

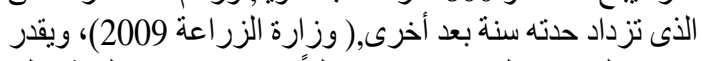

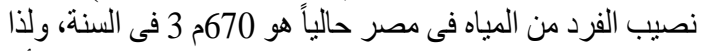

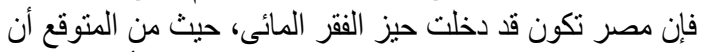

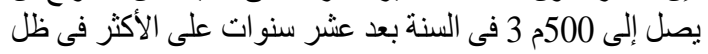




\section{Amany S. A. El Kholy}

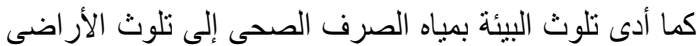

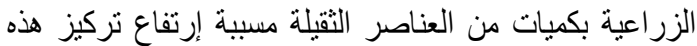

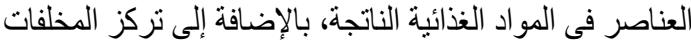

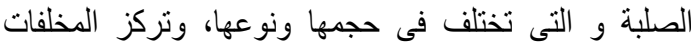

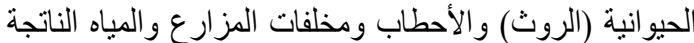

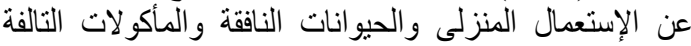

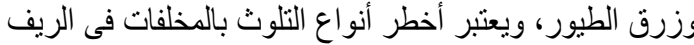

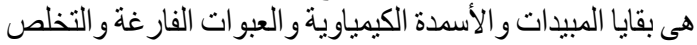

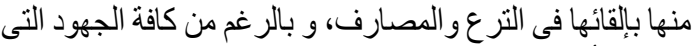

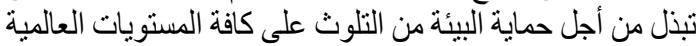

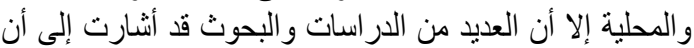

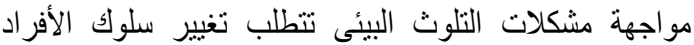

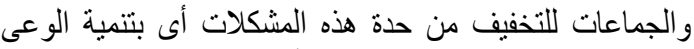

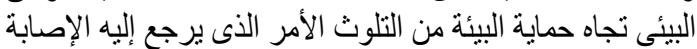

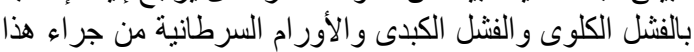

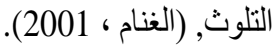

وبناءاً على ما سبق، ولإعتبار ظاهرة التعدى على المجارى

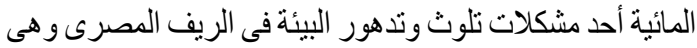

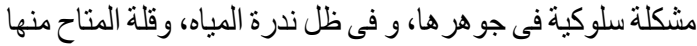

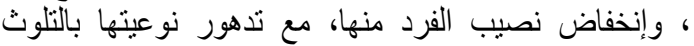

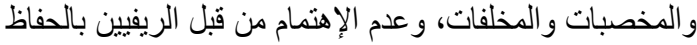

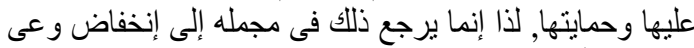

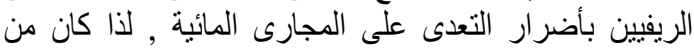

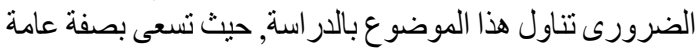

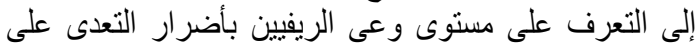

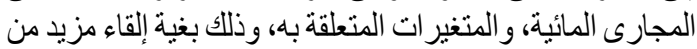

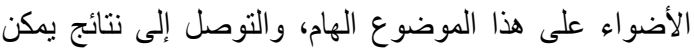

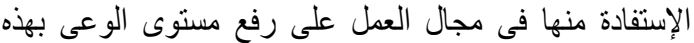
الأضر ار لاى الريفيين، و ترشيد وتقويم سلوكهم البيئى.

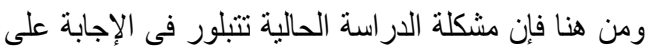

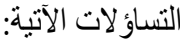

1- ما هو مستوى و الأنهى الريفيين بأضر ار التعدى على المجارى المائية؛

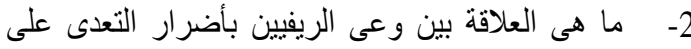
المجارى المائية وبعض بين وعى الرئصهم الشخصية بأضرار الإجنماعية

ما هى أنواع و أسباب التعدى على المجارى المائية وكيفية الحد من هذا التعدى ؟ وأبن

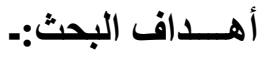

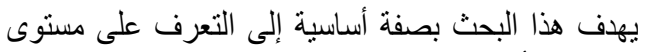

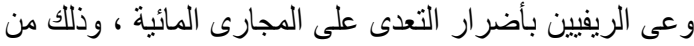

1- التعرف على مستوى وعى الريفيين بأضرار التعدى على التى المجارى المائية. 2- التعرف على الأهمية النسبية لأبعاد و عى الريفيين بأضر ار التعدى على المجارى المائية.

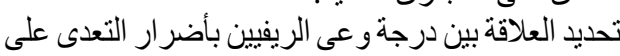
المجارى المائية والمتغير ات المستقلة المدروسة.
ولقد عقدت المؤتمر ات و الندوات و اللقاءات وخططت البر امج

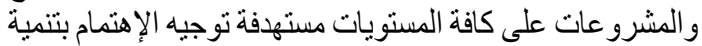

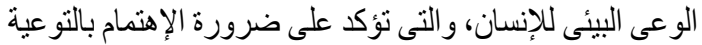

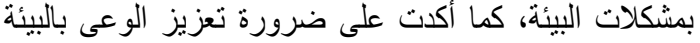

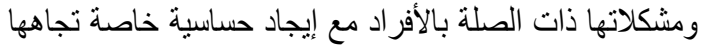

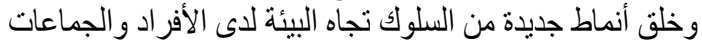

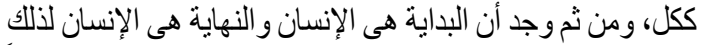

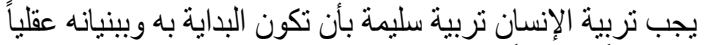

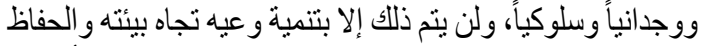

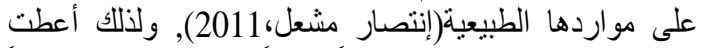

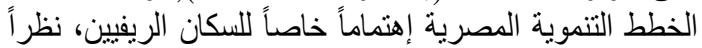

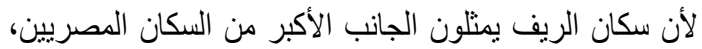
بالإضافة إلى أن الريف هو المسئول عن إثباع الإحتياجات الإنيات الغذائية

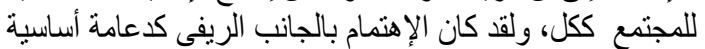

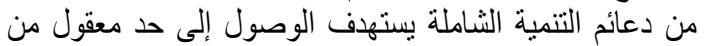

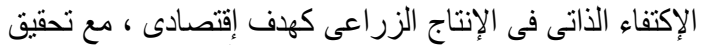

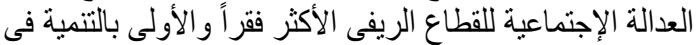
مصر, (الهلباوى،2001).

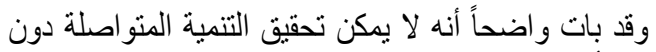

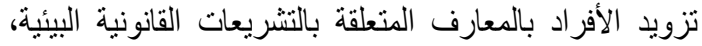

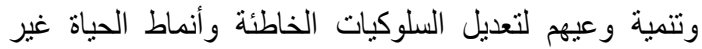

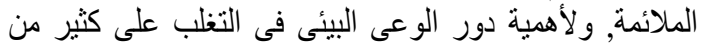

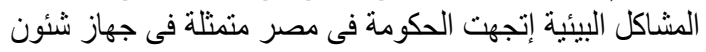

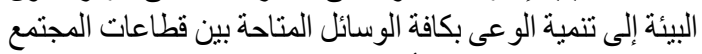

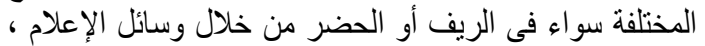

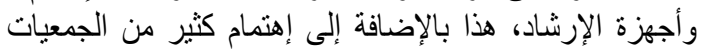

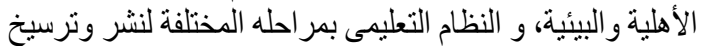
الوعى البيئى وتأهيل وتدريب القوى البشرية فى مجالات العلوم

وأوردت إنتصار مشعل (2011) نقلاً عن سليم أن السياسات

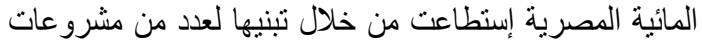

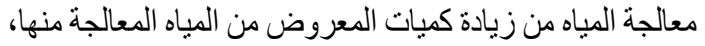

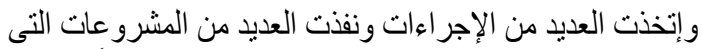

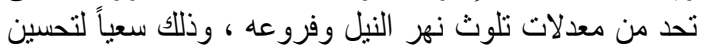

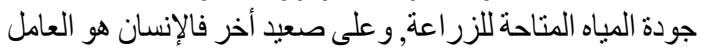

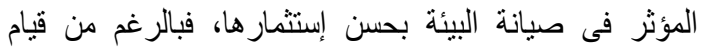

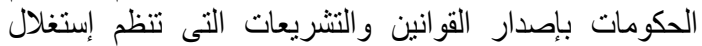

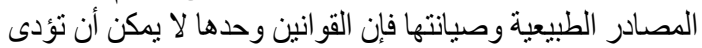

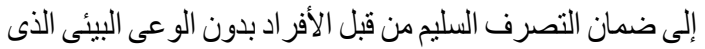

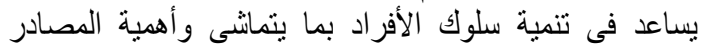

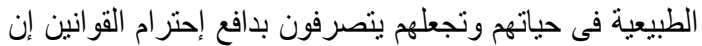

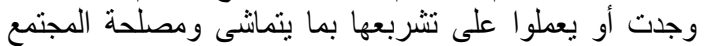
و الفرد على حد سواء.

وتعتبر مشكلة تلوث المياه بمياه الصرف من أهم المشاكل

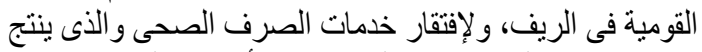

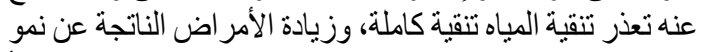

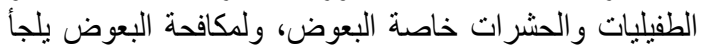

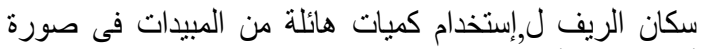

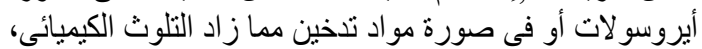




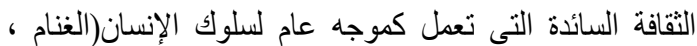
2001)، وكنلك ساهم كل من النمو السكانى المرتفع و إنشاء الكثبر الإني

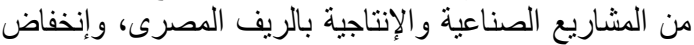

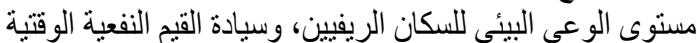

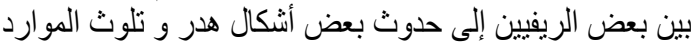

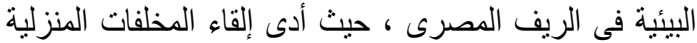

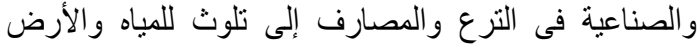

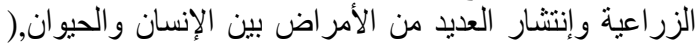
الهلباوى، 2001 ).

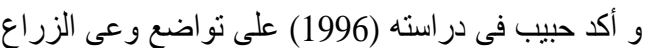

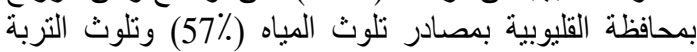

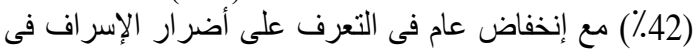

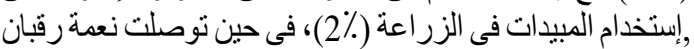

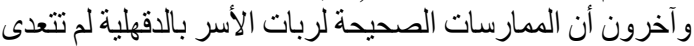

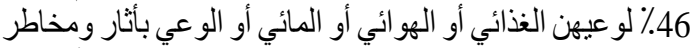

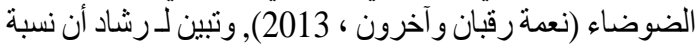

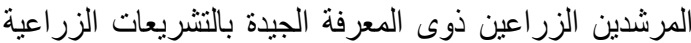

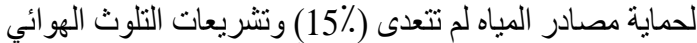

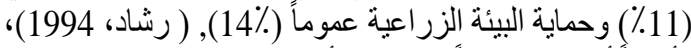

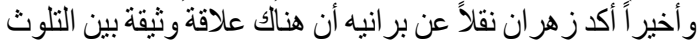

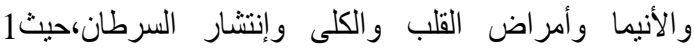

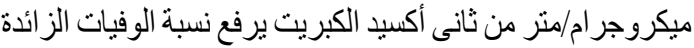

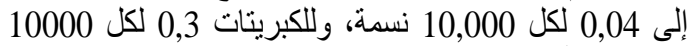
نسمة، ونقاًا عن نجم إلى أن (69, (69) من السكان بلقون بمخلفاتهم

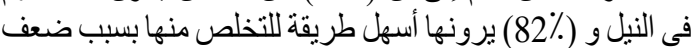
التثريعات والجزاءات وتعدد الجهات المسئولة وغياب الوني لوني البيئي للأفر اد الريفيين (زهر ان،2015).

و ولبه يتضح مدى أهمية دراسة وعى الريفيين بمشكلات

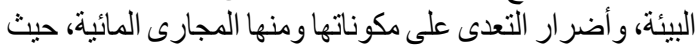

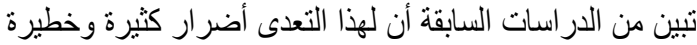

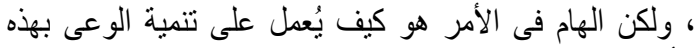

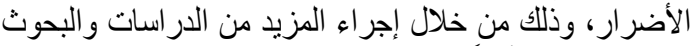

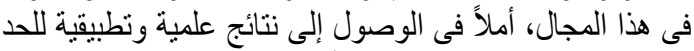

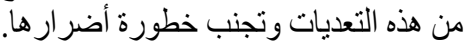

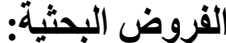

لتحقيق الهدف الثالث للار اسة تم صباغة الفروض البحتية الآتية:

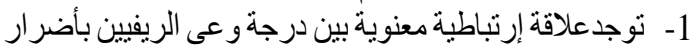

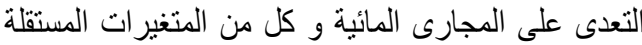
المدروسة على حده.

2- ت توجدعلاقة إرتباطية معنوية بين درجة و على الريفيين بأضر ار التعدى على المجارى المائية و المتغير ات المسنقلة المدروسة مجتمعة.

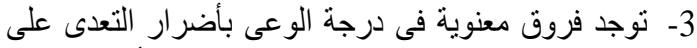

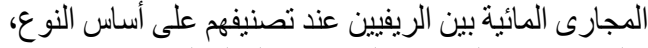

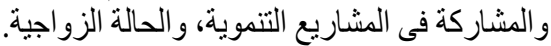

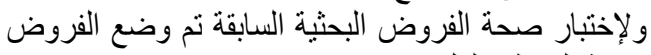
الإحصائية المناظرة لكل منها.

\section{التعريف الإجرائى للمجارى المائية:}

4- التعرف على أنو اعو وأسباب تللك التعديات وكيفية الحد منها.

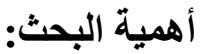

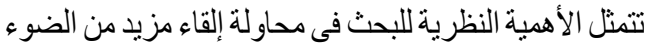

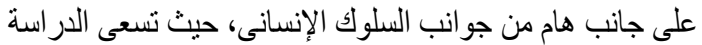

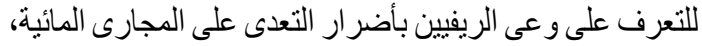

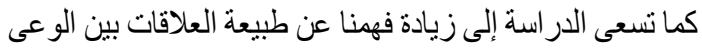

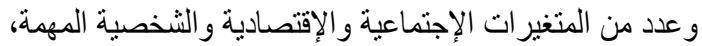
أما الأهمية النطبيقية تتثنل فى مدى إمكانية الإستفادة من نتائج البحث فى تطوير البرامج الإرشادية والتنتية فية والإية والإعلامية

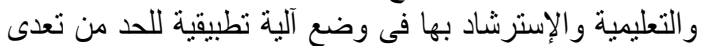

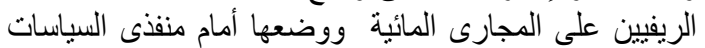

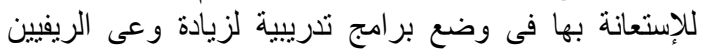

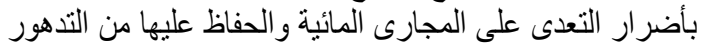

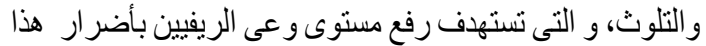
التعدى وتتمية سلوكهم الإيجابى للييئة، و الحد من سلوكهم الضار بلار

\section{الإستعر اض المرجعى:}

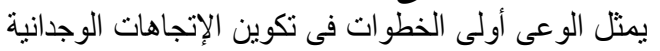

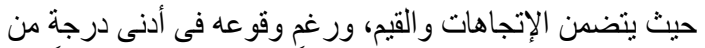

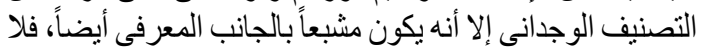

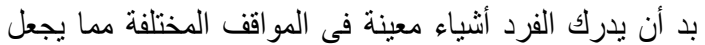

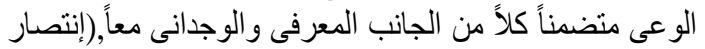

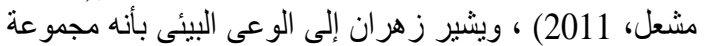

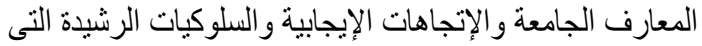

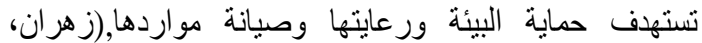

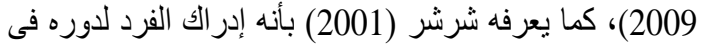

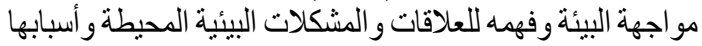

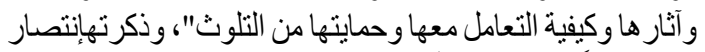

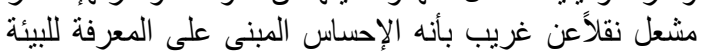

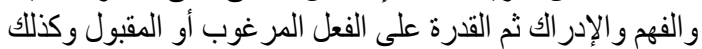

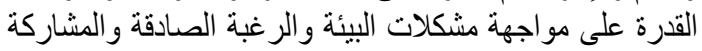

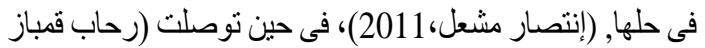

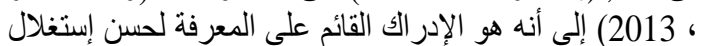

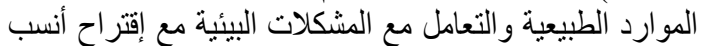

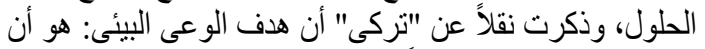

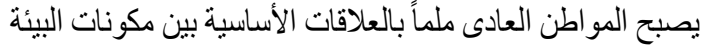

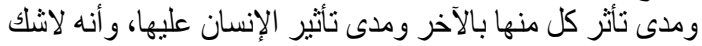

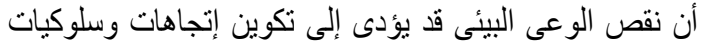

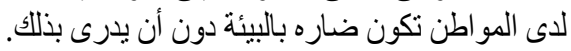

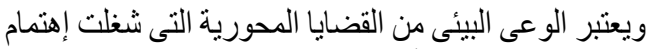

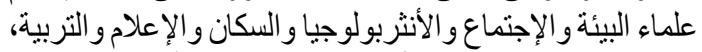

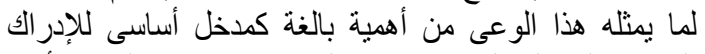

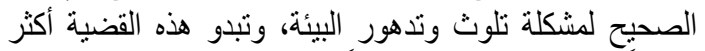

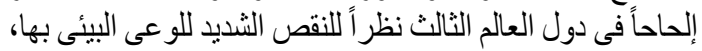

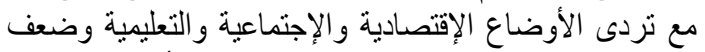
المو ارد المائية وعجز ها عن توفير الإحتياجات الأساسية للسكان، ولإنية

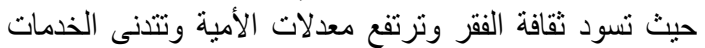

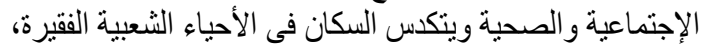

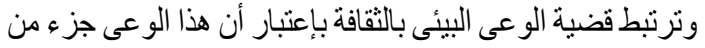


المبحوث فى نفس المنزل وقت جمع البيانات، ويعبر عنه بقيمة رقمية.

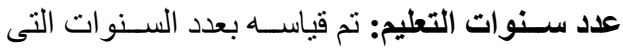

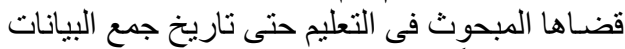

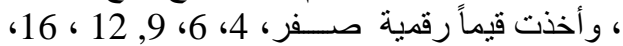

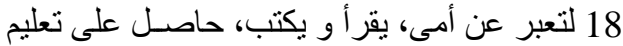

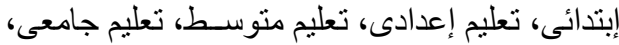

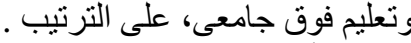

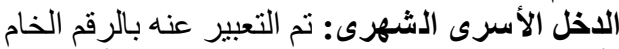

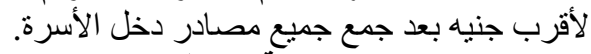

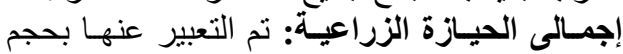

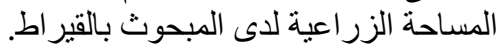

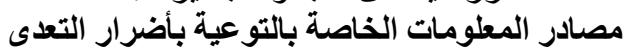

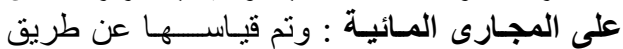

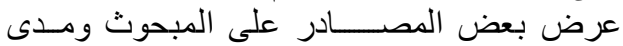

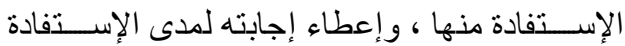

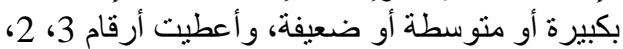

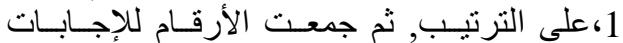

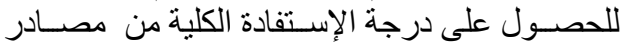

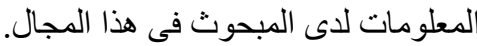

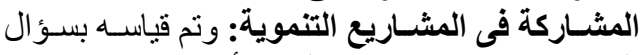

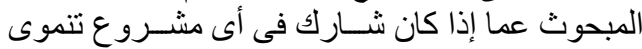

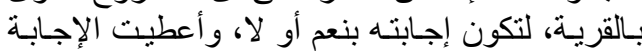

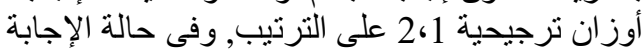

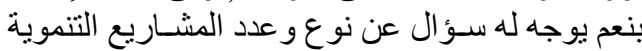

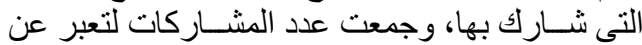
درجة المشاركة .

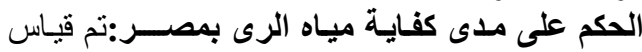

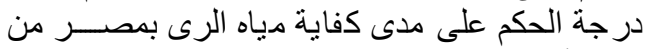

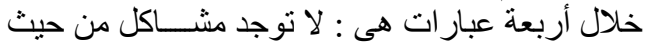

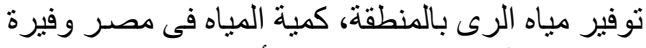

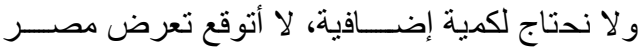

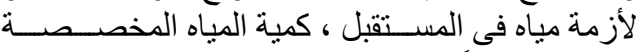

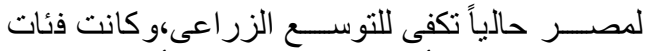

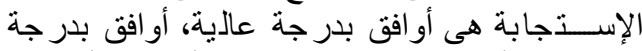

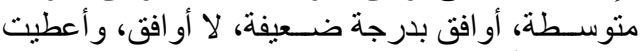

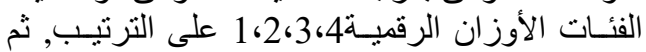

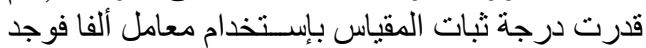

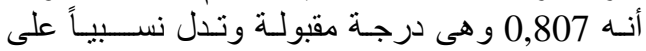

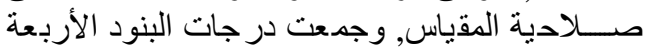

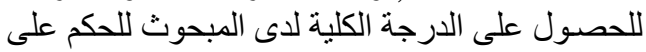

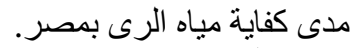

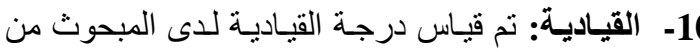

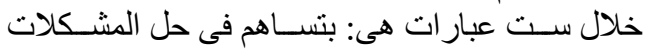

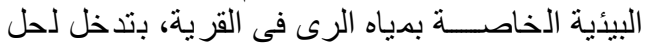

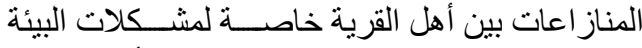

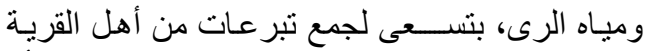

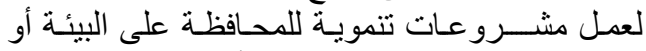

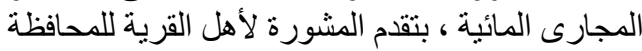

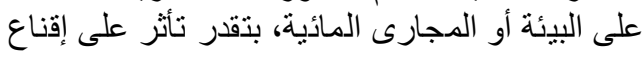

يقصد بالمجارى المائية فى هذا البحث كل مجرى مائى يمر الأئ

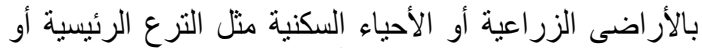

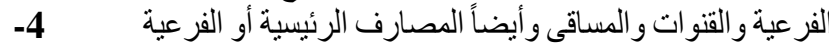

أجرى هذا البحث بمحافظة البحبرة، حيث أنها من أكثر

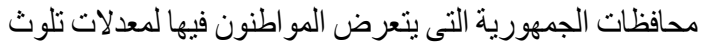

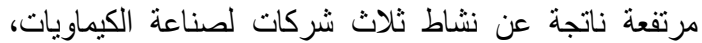

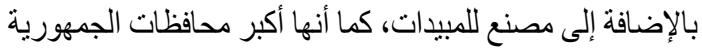

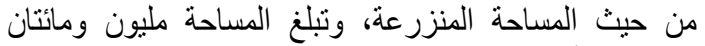

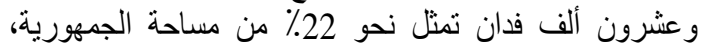

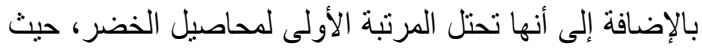

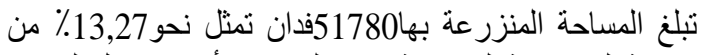

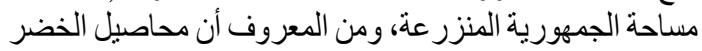

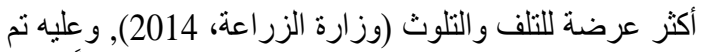

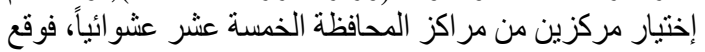

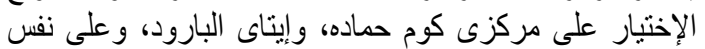

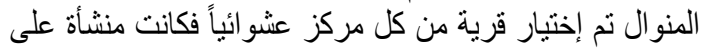

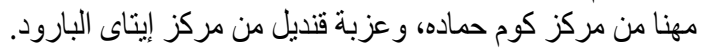

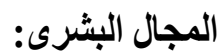

تم حصر عدد الأسر الريفية بالقريتين فكان عدد الأسر الريفية

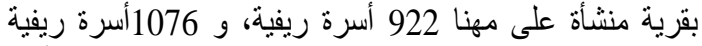

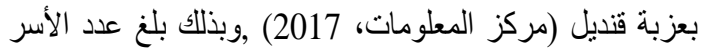

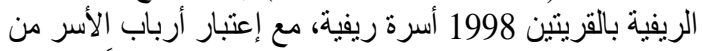

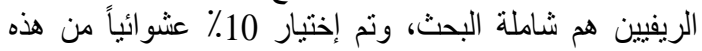

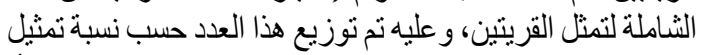

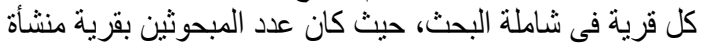

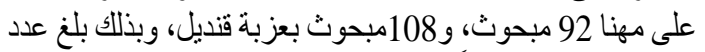
المبحوثين 200مبحوثناً من القريتين .

المنهج العلمى المستخدم فى الدراسة: أستخدم المنهج الوصفى لإجر اء هذه الار اسة.

جمع البيانات:

جمعت البيانات من خلال المقابلة الشخصية بإستخدام إستمارة

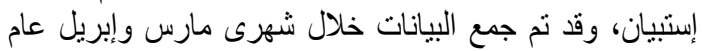

قياس المتغيرات البحثية:

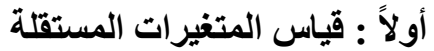

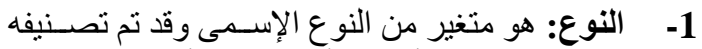

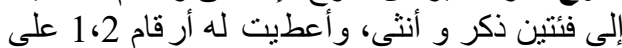
الترنيب.

السـن: تم قياس سـن المبحوث بعدد السـنو ات الكاملة

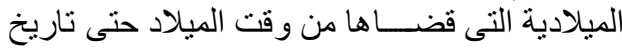
جمع البيانات ويعبر عنه بقيمة رقمية.

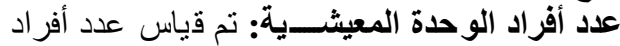

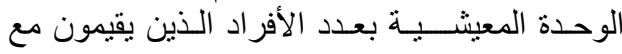


ج - وعى الريفيين بالأضرار البيئية للتعدى على المجارى المائية

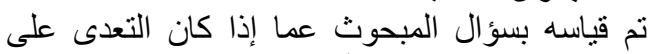

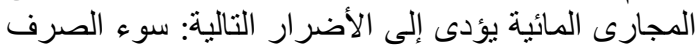

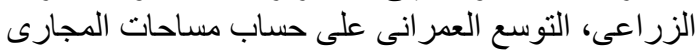

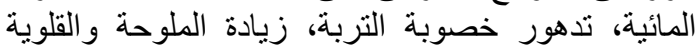

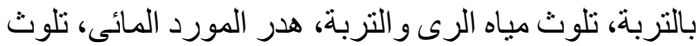

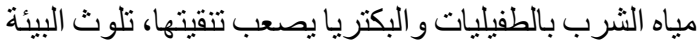

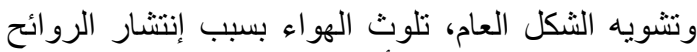

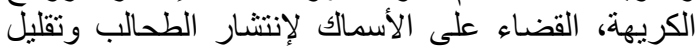

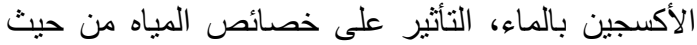

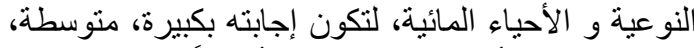

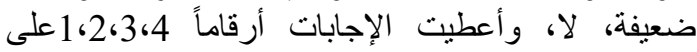

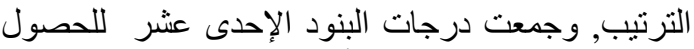
على الدرجة الكلية للوعى بالأضرار البيئية للى المبحوث.

د- وعى الريفيين بالأضرار العقابية للتعدى على المجارى المائية بالأية

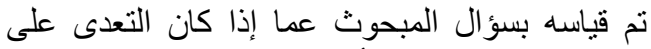

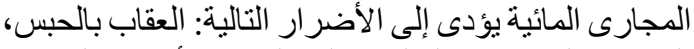
العقاب بالغرامات المالية، المجالس والإلئل الأحكام العرفية،

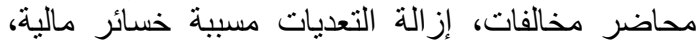

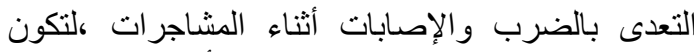

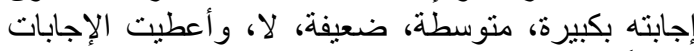

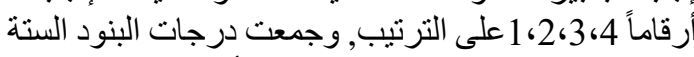
للحصول على الدرجة الكلية للوعى بالأضر اردار العقابية لاى الدى

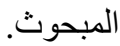

هـ وعى الريفيين بالأضرار الإقتصادية للتعدى على المى المجارى المائية المبية

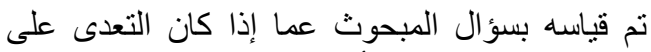
المجارى المائية يؤدى إلى الأضر الئ التالية: ضعف الإن الإنتاجية

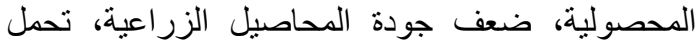

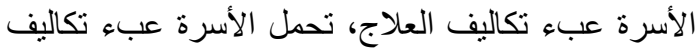

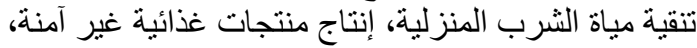

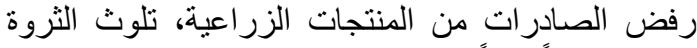

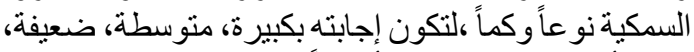
لا، وأعطيث الإجابات أرقاماً

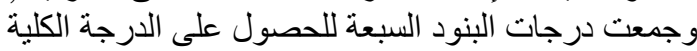

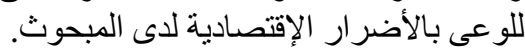

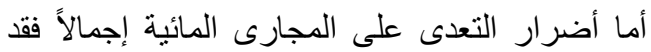

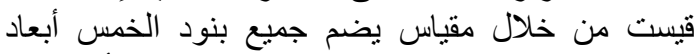
مجتمعة، وقدرت ثبات المقياس بإستخدام معامل ألفا فوجد بـان

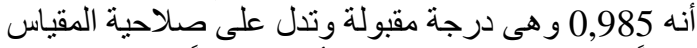

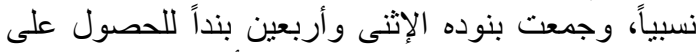

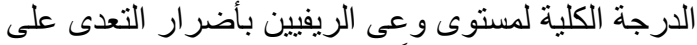

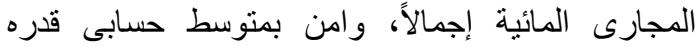

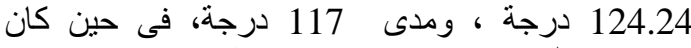
الإنحر اف المعيارى قدره 36.18 درجة .
الأهـالى بالمنطقة للمحافظة على البيئة أو المجارى

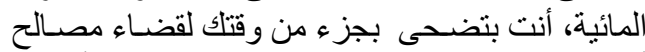
أهل القرية، وكانت فئات الإســتجابة هى دائهـا، أحيانا،

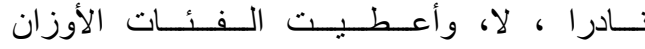

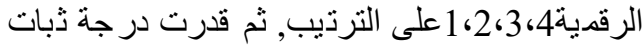
المقياس بإســـتخدام معامل ألفا فوجد أنه بـ

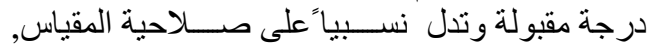

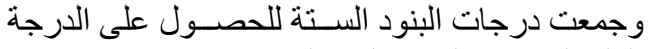

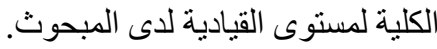

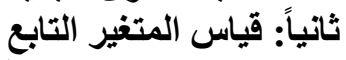

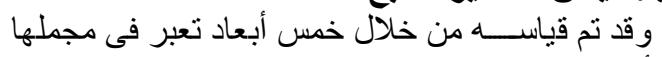
عن أضــرار التعدى على المجارى المائية، حيث تم القياس

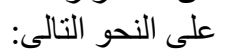

أـ وعى الريفيين بالأضـــرار الإجتماعية للتعدى على المى المجارى المائية بالإن

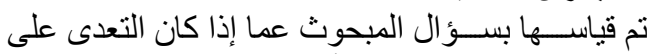

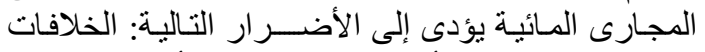

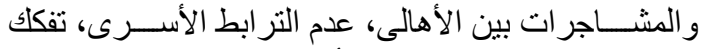

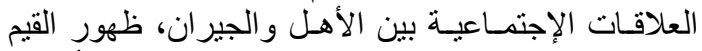

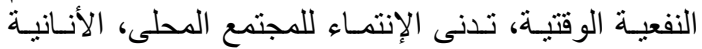

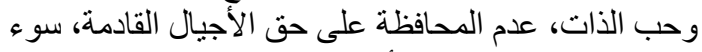

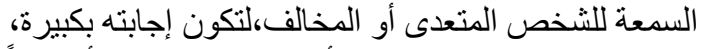

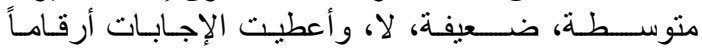

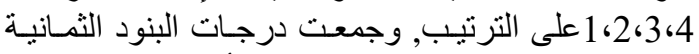
للحصـول على الدرجة الكلية للوعى بالأضـر ار الإجتماعية

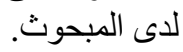

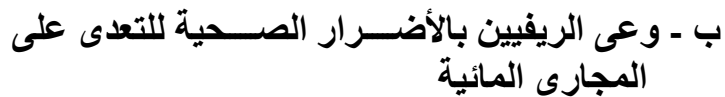
تم قياســـه بســـؤال المبحوث عما إذا كان التعدى على الثى

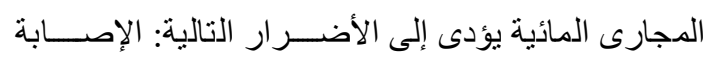
بالنزلات المعوية، الإصابة بالأمر اض الخطيرة كالسرطان

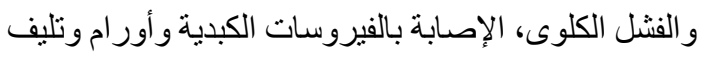

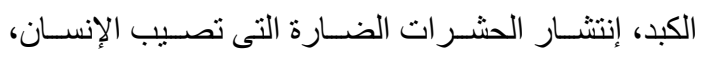

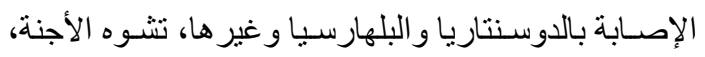

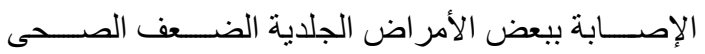
و الخمول و التبلد وعدم القدرة على العمل، بعض أمر اض لاض لإل

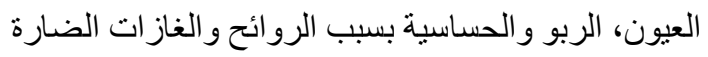

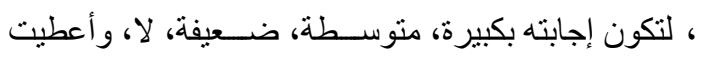

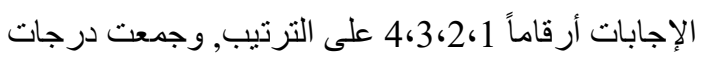

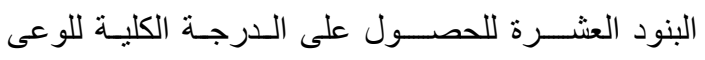
بالأضر ار الصحية لدى المبحوث. 


\section{Amany S. A. El Kholy}

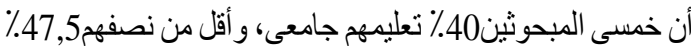

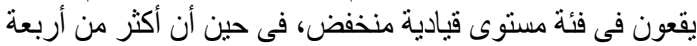

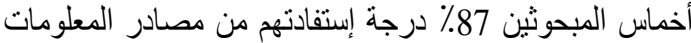

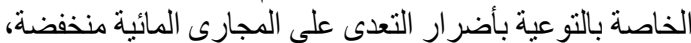

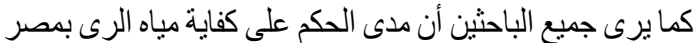
بدرجة منوسطة.

\section{النتائج البحثية ومناقشتها}

أولاً: مستوى وعى المبحوثين بأضرار التعدى على المجارى المائية

أوضحت نتائج الدر اسة الواردة الودة بجدول (2) أن غالبية

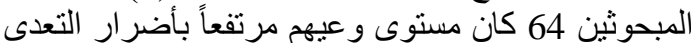

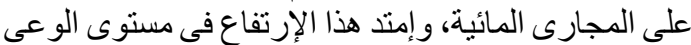
على كل من الوعى بالأضرار الإجتماعية، والصية والصحية،

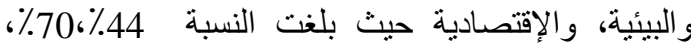

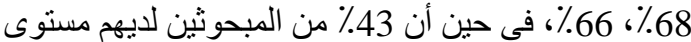
وعى منخفض بالأضرار العقابية للتعدى على المجارى لـى لإنى

المائية.

من العرض السابق يتبين وجود و وعى مرتفع نسبياً لدى

الريفيين بأضرار التعدى على المجارى المائية، وإن كان هذا الو عى لا يعنى بالضرورة التعامل مع قضية التعدى على بلى المجارى المائية بشكل إيجابى, فى حين أظهرت بهرت نتائج الدر اسة وجود نسبة تعديات من الريفيين وبأكثر من شكل، بهابل

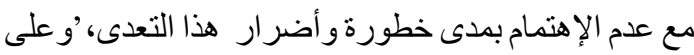
الرغم من وجود و عى لديهم بهذه الأضر ار الخطيرة.
ثُالثاً: التعرف على أنواع وأسباب التعدى على المجارى

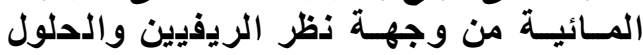

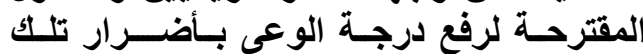
التعدياث

تم التعرف على أنو اع التعدى على المجارى المائية من خلال

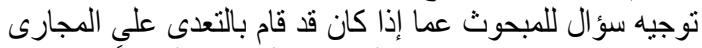

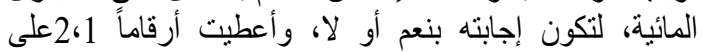

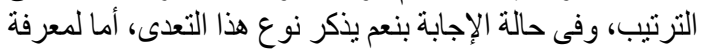

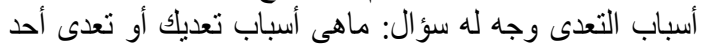

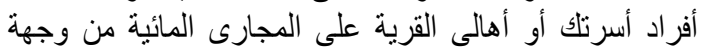

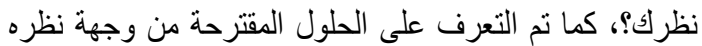

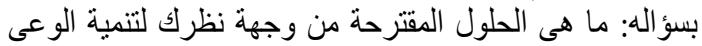

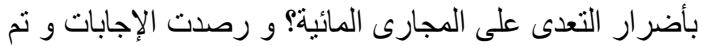
عمل التكر ار ت لهان.

\section{أسـاليب التحليل الإحصائى:}

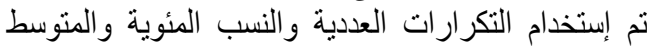

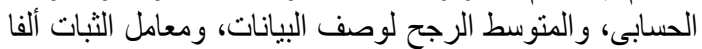

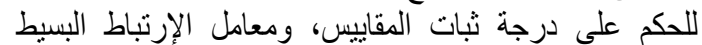

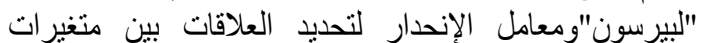
البحث، و إختبار (ت) و إختبار تحليل التباين.

\section{وصف خصائص المبحوثين:}

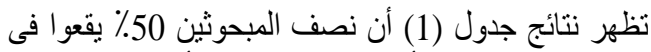

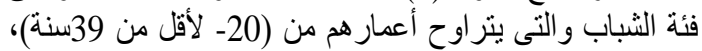

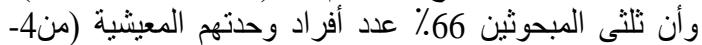
6أفراد)، كما إتضح أن أكثر من ثناثنة أرباع المبحوثين78\%

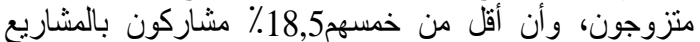

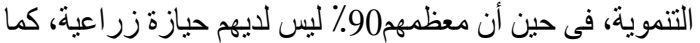
جدول رقم (1): توزيع المبحوثين وفقاً لخصائصهم الثخصية وانهية الإجتماعية

\begin{tabular}{|c|c|c|c|c|c|c|c|c|}
\hline$\%$ & التكر ار & المتغير & $\%$ & التكر ار & المتغير & $\%$ & التكر ار & المتغير \\
\hline & & 9- عدد سنو ات التعليج & & & 5-المشاركة بالمشاريع & & & 1 1-النوع \\
\hline & & أمى & & & ال التنموية & & & ذكر \\
\hline 26,5 & 53 & & 18,5 & 37 & يشارك & 40 & 80 & \\
\hline 2 & 4 & 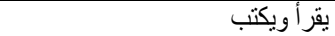 & 81,5 & 163 & ل لا يشارك & 60 & 120 & أنثى \\
\hline & & 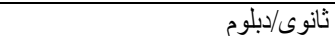 & & & 6-الحيازة الزراعبة & & & 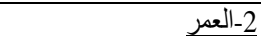 \\
\hline 19,5 & 39 & & 90 & 180 & ل لا يوجد & 50 & 100 & (من 20- أقل من 39سنة) \\
\hline O & 80 & جامعى & 6 & 12 & | مناقبر اط ـ أقلّل من & 26,5 & 53 & (من39-أقل من48سنة) \\
\hline 40 & 80 & & & & (24) مقير اط) & & & \\
\hline 12 & 24 & 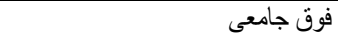 & 4 & 8 & 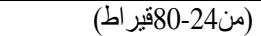 & 23,5 & 47 & (من48-65سنة) \\
\hline & & 10- الإستفادة من مصادر المعلومات & & & 7-الدخل الشهرى بالجنيه & & & 3-عدد أفر اد الوحدة المعيشية \\
\hline 87 & 174 & منخفضة (من9-أقل من16درجة) & 80 & 160 & (من950-أقل من 2600) & 18 & 36 & (من3أفر اد فأقل) \\
\hline 11 & 22 & متوسطة(من16-أقل مندرجة22) & 18 & 36 & | (من2600-أقل من4200) & 66 & 132 & (من4-6 أفر اد) \\
\hline 2 & 4 & مرتفعة (من22-27درجة) & 2 & 4 & | & 16 & 32 & (أكثر من 6 أفر اد) \\
\hline & & 11-مدى الحكم على كفاية مياه الرى & & & 8-القيادية & & & 4-الحالة الزواجية \\
\hline & & بمصر & & & منخفضة (من6-أقل من12) & & & أعزب \\
\hline 0 & 0 & منخفضة (من4-أقل من8درجة) & 47,5 & 95 & & 8 & 16 & \\
\hline 100 & 200 & متوسطة(من 8 أقل من12درجة) & 39 & 78 & متوسطة(من12-أقل من18) & 78 & 156 & 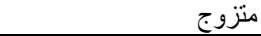 \\
\hline \multirow[t]{2}{*}{0} & 0 & مرتفعة(من12-16درجة) & 13,5 & 27 & مر تفعة (من18-24) & 10 & 20 & 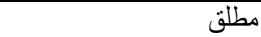 \\
\hline & & & & & & 4 & 8 & 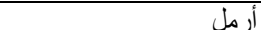 \\
\hline
\end{tabular}

جدول (2): توزيع المبحوثين وفقاً لمستوى وعيهم بأضرار التعدى على المجارى المائية

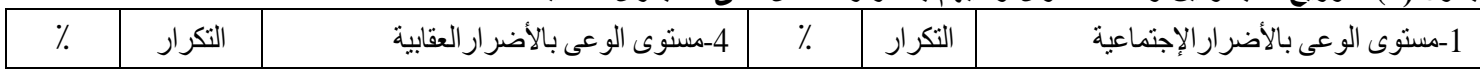


Rural people awareness of aggression disadvantages on waterways In

\begin{tabular}{|c|c|c|c|c|c|}
\hline 43 & 86 & منخفض(من6-أقل من13 درجة) & 22,2 & 45 & منخفض(من8_أقل من17درجة) \\
\hline 25 & 50 & منو سط(من13-أقل من19 درجة) & 33,5 & 67 & متو سط(من17-أقل من25 درجة) \\
\hline 32 & 64 & مرتفع(من19-24 درجة) & 44 & 88 & مرتفع(من25-32 درجة) \\
\hline \multicolumn{3}{|r|}{ 5-مستوى الوعى بالاضضر ار الإقتصادية } & \multicolumn{3}{|r|}{ 2-مستوى الوعى بالأضر ار الصحية } \\
\hline 24,5 & 49 & منخفض(من7-أقل من15 درجة) & 24,5 & 49 & منذفض(من10-أقل من21 درجة) \\
\hline 9,5 & 19 & منو سط(من15-أقل من22 درجة) & 5,5 & 11 & متوسط(من21-أقل من31 درجة) \\
\hline 66 & 132 & مرتفع(من22-28 درجة) & 70 & 140 & مرتفع(من31-40 درجة) \\
\hline \multicolumn{3}{|r|}{ 6-مستوى الوعى بأضر ار إجمالاً } & \multicolumn{3}{|r|}{ 3-مستوى الوعى بالأضر ار البيئية } \\
\hline 22,5 & 45 & منخفض(من42-أقل من84 درجة) & 22,5 & 45 & منخفض (من11-أقل من23 درجة) \\
\hline 13,5 & 27 & متوسط(من84-أقل من126 درجة) & 9,5 & 19 & متو سط (من23-أقل من34 درجة) \\
\hline 64 & 128 & مرتفع(من126-168 درجة) & 68 & 136 & مرتفع (من34-44 درجة) \\
\hline
\end{tabular}

مصادر المعلومات، درجة المشاركة فى المشاريع التنموية، درجة الحكم على مدى كفاية مياه الرى، درجة القيادية,"وقد أستخدم فى إختبار هذا الفرض معامل الإرتباط البسيط، و الجدول رقم (4) يوضح أهم النتائج، حيث تبين وجود علاقة إرتباطية معنوية موجبة بين درجة و وعى المبحوثين بأضر ار التعدى على المجارى المائية إجمالاً وكل من: عدد سنو ات التعليم، و درجة الإستفادة من مصادر المعلومات، و درجة القيادية حيث بلغت قيمة معامل الإرنباط بينهم 0,875، 0,456، 0,316 على الترتيب، وهى جميعها عالية المعنوية عند مستوى معنوية 0,01، ولم يتبين وجود علاقة بين بين درجة وعى المبحوثين بالأضر ار التعدى على المجارى المائية إجمالاً وكل من: سن المبحوث،عدد أفراد الوحدة المعيشية، الدخل الأسرى الشهرى،حجم الحيازة الزر اعية، ودرجة المشاركة فى المشاريع التنموية، و درجة الحكم على مدى كفاية مياه الرى، مما يعنى أن زيادة كل من: عدد سنوات التعليم، ودرجة الإستفادة من مصادر المعلومات، و درجة القيادية تزيد من درجة وعى المبحوثين بأضرار التعدى على المجارى المائية إجمالاً, وبذلك يمكن رفض الفرض الإحصائى وقبول الفرض البحثى جزئياً.
ثانياً: الأهمية النسبية لأبعاد الوعى بأضرار التعدى التي

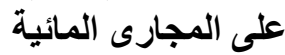

وبشىء أكثر تفصيلاً تبين نتائج جدول (3) الأهمية النسبية لأبعاد الو عى بأضر ار التعدى على المجارى المائية، حيث تبين أن هناك خمس أبعاد مرتبة وفقاً للمتوسط الرجح كالآتى: الوعى بالأضرار البيئية للتعدى على المجارى المائية (3,15) درجة، يليها الوعى بالأضرار الصحية $(3,14)(3,08)(3)$ درجة، ثم الوعى بالأضرار الإقتصادية درجة، يليها الوعى بالأضرار الإجتماعية (2,72) درجة،

$$
\text { و أخيراً الوعى بالأضرار العقابية }(2,45) \text { درجة. }
$$

ثالثاً: أـ العلاقة الإرتباطية بين درجة وعى المبحوثين

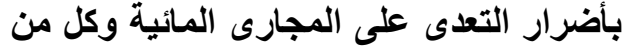
المتغيرت المستقلة المدروسة على المدى حده لإختبار الفرض البحثى الأول للاراسة تم صياغة الفرض الإحصائى الآتى:"لا توجد علاقة إرتباطية معنوية بين درجة و وعى المبحوثين بأضر ار التعدى على المجارى المائية وبين كل من المتغيرات التالية : سن المبحوث، عدد أفر اد الوحدة المعيشية، عدد سنوات التعليم، الدخل الأسرى الشهرى ، حجم الحيازة الزراعية، درجة الإستفادة من جدول (3): يبين الأهمية النسبية لأبعاد الوعى بأضرار التعدى على المجارى المائية 
Amany S. A. El Kholy

\begin{tabular}{|c|c|c|c|c|}
\hline الأول & 3,16 & 11 & 34,71 & بالأضر ار البيئية \\
\hline الثانى & 3,15 & 10 & 31,45 & بالأضر ار الصحية \\
\hline الثالث & 3,09 & 7 & 21,6 & بالأضر ار الإقتصادية \\
\hline الر ابع & 2,72 & 8 & 21,77 & بالأضر ار الإجتماعية \\
\hline الخامس & 2,45 & 6 & 14,72 & لأضر ار العقابية \\
\hline
\end{tabular}

جلول (4): العلاقةة الإرتباطيةٌ والإنداريةٌ بين خصائص المبحوثين المدروسة ودرجة وعيهم بأضرار التعدى على المجارى

\begin{tabular}{|c|c|c|c|}
\hline \multicolumn{2}{|c|}{ الوعى بأضر ار التعدى على المجارى المائية جميعها } & \multirow{2}{*}{ المتغير ات المستقلة } & \multirow{2}{*}{ s } \\
\hline معامل الإنحدار & معامل الإرتباط البسيط & & \\
\hline$* * 0,116$ & 0,08 & سن المبحوث & 1 \\
\hline$* * 0,118$ & $0,073-$ & عدد أفر اد الوحدة المعيشية & 2 \\
\hline$* * 0,924$ & $* * 0,875$ & عدد سنوات التعليم & 3 \\
\hline$* * 0,159$ & 0,099 & الدخل الأسرى الشهرى & 4 \\
\hline$* 0,109$ & 0,137 & حجم الحيازة الزر اعية & 5 \\
\hline $0,022-$ & $* * 0,456$ & درجة الإستفادة من مصادر المعلومات & 6 \\
\hline $0,064-$ & 0,129 & درجة المشاركة فى المشاريع التنموية & 7 \\
\hline$* 0,074$ & $0,037-$ & درجة الحكم على مدى كفاية مياه الرى & 8 \\
\hline 0,089 & $* * 0,316$ & درجة القيادية & 9 \\
\hline \multicolumn{2}{|c|}{0,899} & $\overline{\mathrm{R}}$ & \\
\hline \multicolumn{2}{|c|}{0,808} & $\mathrm{R} 2$ & \\
\hline \multicolumn{2}{|c|}{$* * 88,722$} & قيمة F F & \\
\hline
\end{tabular}

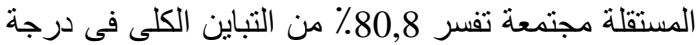

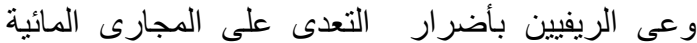

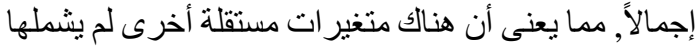

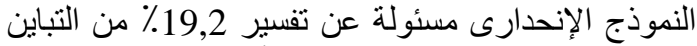

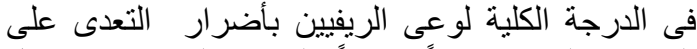

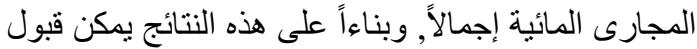
الفرض البحثى ورفض الفرضئر الفرضاءل الإحصائى.

رابعاً: الفروق فى درجة وعى المبحوثين بأضرار

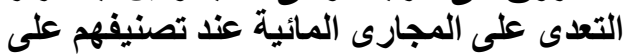

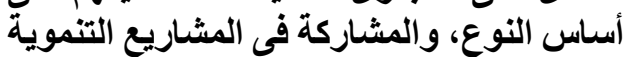

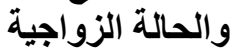
أ-نتائج إختبار (ت) للتعرف على الفئل الفروق المعنوية بين

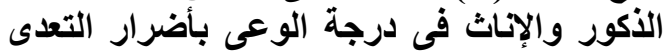
على المجارى المائية

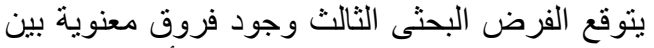

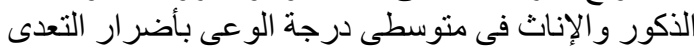

ب - العلاقة الإرتباطية بين درجة وعى الريفيين

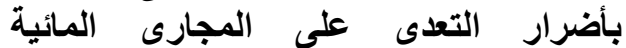
والمتغيرات المستقلة المدروسة مجتمعة المبحة

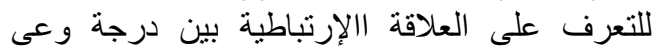

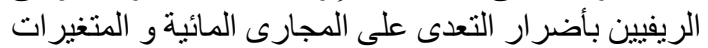

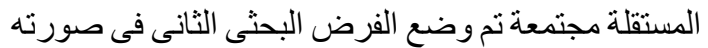

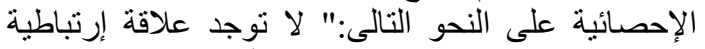

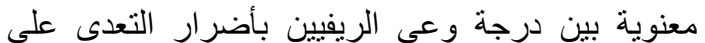

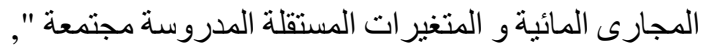

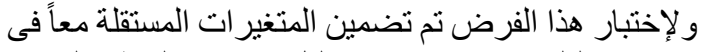

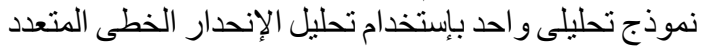

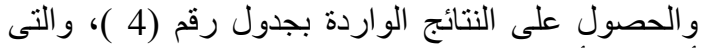

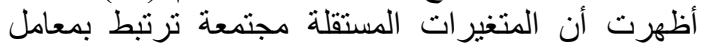

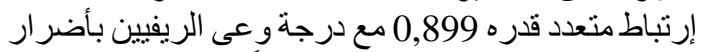

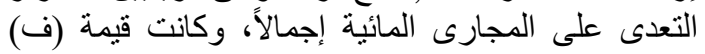

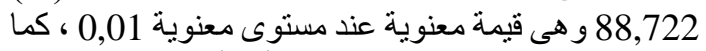
بلغت قيمة معامل التحديد 0,808، أى أن هذه المتغيرات 
المساهمة فى حل المشكلات البيئية بالريف المصرى، كما

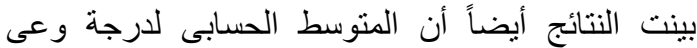

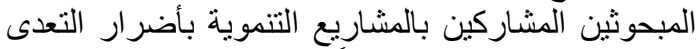

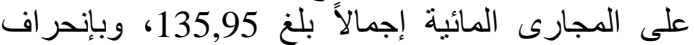

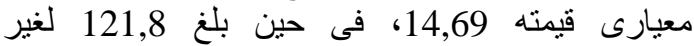

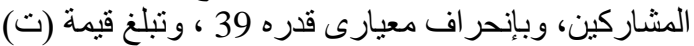

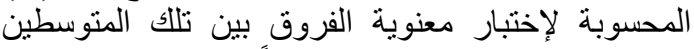

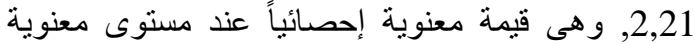

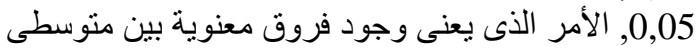

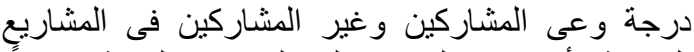
التنموية بأضرار التعدى التعى على المجارى المائية إجمالاًر

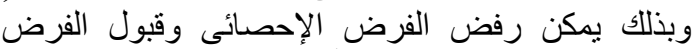

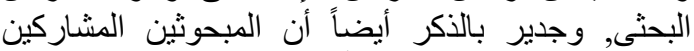

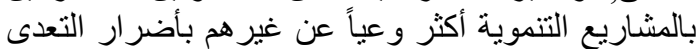

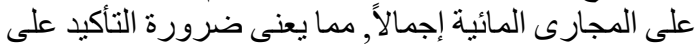

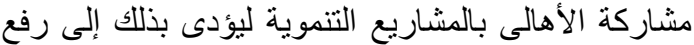

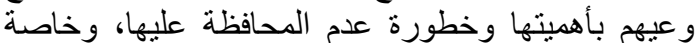
بالأضرار الناتجة من التعامل معها بأها بالسلوكيات السلبية مسببة بذلك أضر ار كثيرة تهدد حياة الريفيين.
على المجارى المائية، وتم إختبار هذا الفرض فى صورته

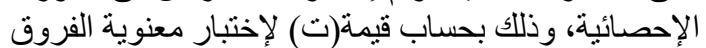

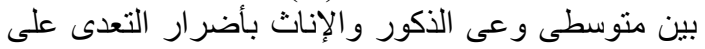
المجارى المائية, ويعرض وعن جدول (5) النتائج المتحصل والأن عليها.

يتضح من النتائج الواردة بجدول (5) أن المتوسط

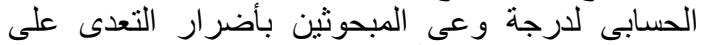

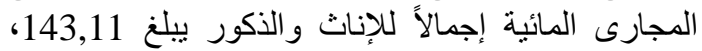
95,94 على الترنيب، وبإنحر اف معيارى قيمته الته

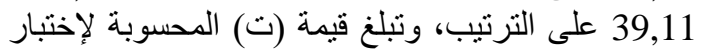
معنوية الفروق بين تلك المتوسطين 11,73, وهنى فئ قيمة

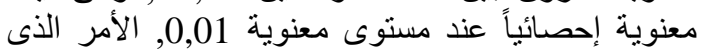

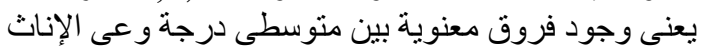
و الذكور بأضرار التعدى على المجارى المائية إجمالاً , الإنات

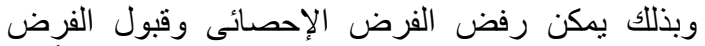

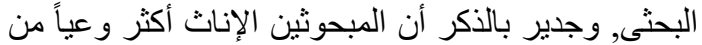

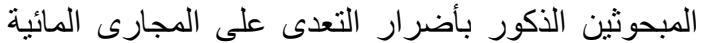

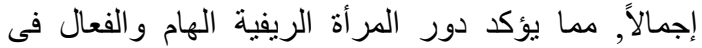

جدول (5): نتائج إختبار (ت) لمعنوية الفروق بين متوسطى درجة وعى المبحوثين بأضرار التعدى على المجارى المائية

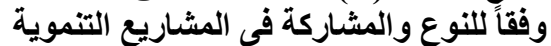

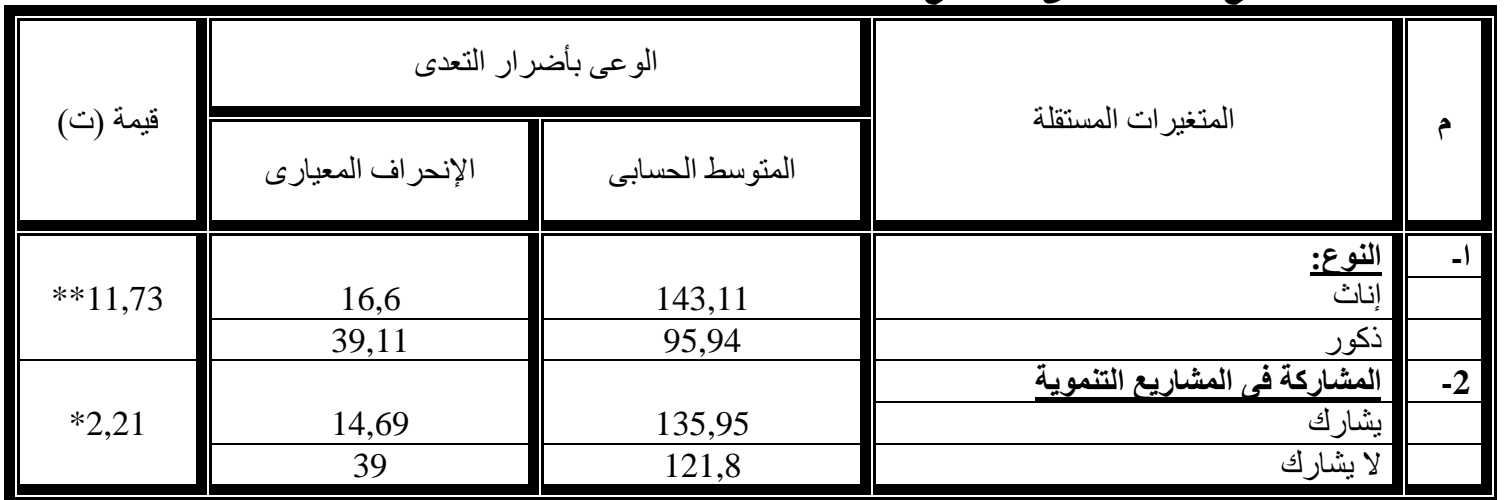

بأضرار التعدى على المجارى المائية إجمالاً عند تصنيفهر

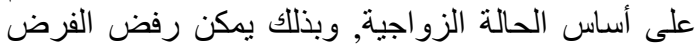
الإحصائى وقبول الفرض البحثى.

خامساً: أنواع وأسباب التعدى ومقترحات المبحوثين لتنمية الوعى بأضرار التعدى على المجات المبارى المائية

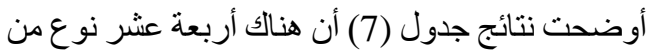

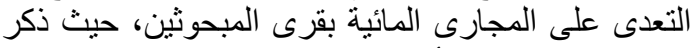

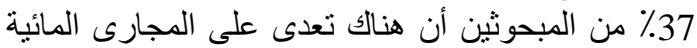

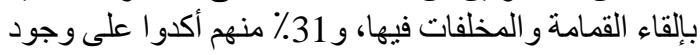

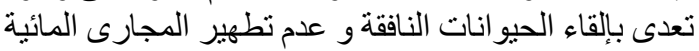

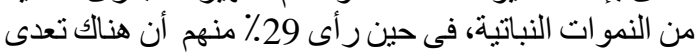

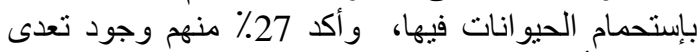

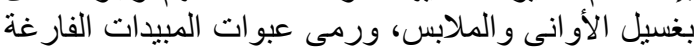
بهاهو رأى 21,5٪ أنه يو جد تعدى من خلال قضاء الحاء الحاجة
بـ نتائج إختبار تحليل التباين للتعرف على الفروق

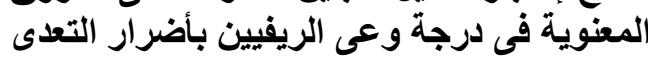

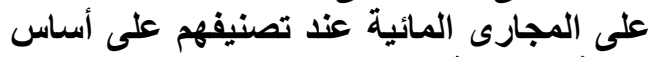
الحالة الزواجية المباري ينوقع الفرض البحثى الثالث وجود فروق معنوية بين

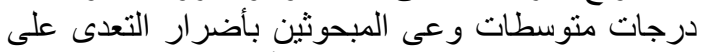

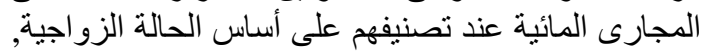

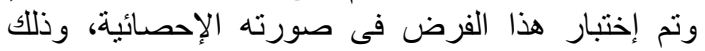

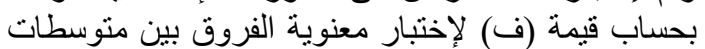

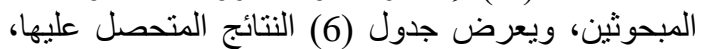

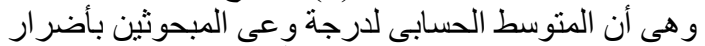

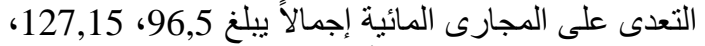

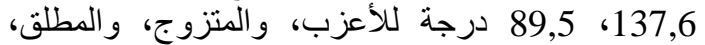
و الأرمل على الترتيب, وتبلغ قيمة لفرة) المحسوبة لإختبار

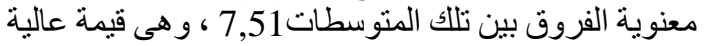

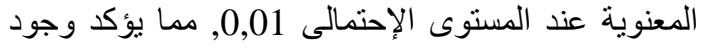
فروق معنوية بين متوسطات درجة وعى المبحوثين 
بالقرية هو سبب تعديهم، فى حين ذكر أكثر من نصفهم 54٪ أن سبب التعدى أنهم إنعودوا على تلك الأفعال (موروث

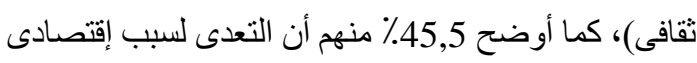
وهو : توفير مكان لبهائمهم وللراحة وزراعة بعض

$$
\text { الخضروات و التشوينات. }
$$

بالدجارى المائية ، فى حين ذكر 14٪ فأقل باقى أنواع

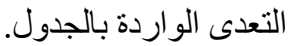
كما أظهرت نتائج جدول رقم (8) أن أسباب تعدى المبحوثين أو ذويهم على المجارى المائية كان : عدم وجود مكان مخصص لتجميع القمامة و المخلفات هو سبب تعدى لهى أكثر من ثلثى المبحوثين 69٪ على المجارى المائية، كما

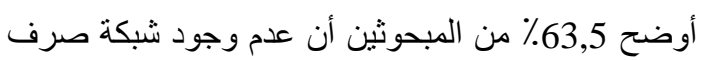

جدول (6): إختبار تحليّ التباين لمعنوية الفروق بين متوسطات درجة وعى المبحوثين بأضرار التعدى على المجارى المائية وفقاً للحالة الزواجية التباين

\begin{tabular}{|c|c|c|}
\hline قيمة (ف) & متوسط درجة الوعى بأضرار التعدى إجمالاً & الحالة الزواجية \\
\hline & 96,5 & أعزب \\
\hline \multirow[t]{3}{*}{$* * 7,51$} & 127,15 & 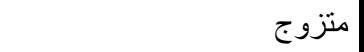 \\
\hline & 137,6 & مطلق \\
\hline & 89,5 & 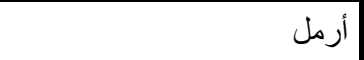 \\
\hline
\end{tabular}

\begin{tabular}{|c|c|c|}
\hline$\%$ & 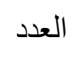 & 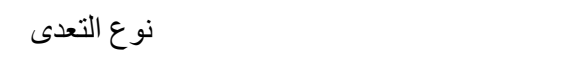 \\
\hline 6 & 12 & 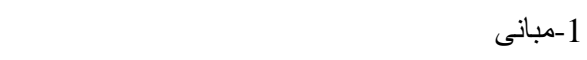 \\
\hline 8 & 16 & 2-زراعات هامشية \\
\hline 14 & 28 & 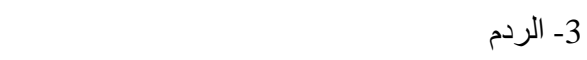 \\
\hline 6 & 12 & 4- تشوينات \\
\hline 2 & 4 & 5- قطع جسور \\
\hline 14 & 28 & 6- فتحات رى خاصة \\
\hline 10 & 20 & 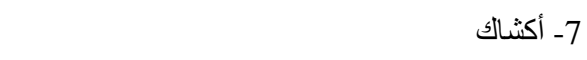 \\
\hline 37 & 60 & 8- إلقاء قمامة و المخلفات \\
\hline 31 & 62 & 9- إلقاء حيو انات نافقة \\
\hline 27 & 54 & 10-غسيل أو انى أو ملابس \\
\hline 27 & 54 & 11-رمى عبوات المبيدات الفار غة \\
\hline 29 & 58 & 12-إستحمام الحيو انات \\
\hline 21,5 & 63 & 13-قضاء الحاجة فى مياه المجارى المائية \\
\hline 31 & 62 & 14- عدم تطهير المجارى المائية من النموات النباتية \\
\hline
\end{tabular}


جدول رقم (8): توزيع إجابات المبحوثين وفقاً لأسباب التعدى على المجارى المائية

\begin{tabular}{|c|c|c|}
\hline 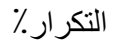 & العدد & 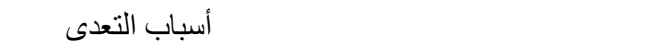 \\
\hline 69 & 138 & 1-عدم وجود مكان مخصص لتجميع القمامة و المخلفات \\
\hline 63,5 & 127 & 2-عدم وجود شبكة صرف بالقرية \\
\hline 54 & 108 & 3-إتعودنا على كده( معتقد ثقافى) \\
\hline 45,5 & 91 & 4-لتوفير مكان للبهائم والر احة وزر اعة الخضار و التشوينات \\
\hline
\end{tabular}

من العرض السابق ينضح أن أسباب التعدى على يقرب من النصف 48٪ على ضرورة نوفير وسائل أمنة

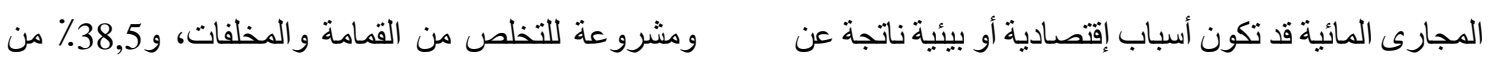
عدم تو افر البنية التحتية (شبكة صرف صحى جيدة بالقرية)، المبحوثين أتفقو ا على ضرورة تعاون المحليات و وزارة و وعدم وجود جهاز فعال لثؤن البيئية وعدم نوفير سيارات الزراعة و وزارة الرى و الموارد المائية لتقديم حل جذرى لتجميع القمامة و المخلفات بالقرية بشكل دورى ومنو اصل. ششامل للمشكلة، كما أوصى 36,5٪ من المبحوثين بتفعيل يتبين من نتائج جدول رقم (9) أن أكثر من نصف القانون وتظغيظ العقوبات والإستمرار فى حملات الإزالات المبحوثين 58,5\% كانت مقترحاتهم متفقة على ضرورة بشكل مستمر ، وأكد 24,5٪ منهم على أهمية الإكثار من تطهير المجارى المائية بإستمرار ، كما إقترح نصف الحملات الإعلامية القوية والمستمرة فى شتى وسائل المبحوثين 50٪ عمل ندوات ومحاضرات تثقيفية لزيادة الإعلام، واتفق 20,5٪ من المبحوثين على ضرورة نوفير الوعى بأضرار التعدى على المجارى المائية ، و أكد ما شبكة صرف صحى جيدة بالقرية. جدول رقم (9): توزيع المبحوثين وفقاً لمقترحاتهم التمية الوعى بأضرار التعدى على المجارى المائية

\begin{tabular}{|c|c|c|}
\hline 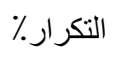 & العدد & الحلول المقترحة \\
\hline 58,5 & 117 & 1-تطهير المجارى المائية بإستمرار \\
\hline 50 & 100 & 2-عمل ندوات ومحاضر ات لزيادة الوعى البيئى و التشريعى \\
\hline 48 & 96 & 3-نوفير وسائل أمنة ومشرو عة للتخلص من القمامة و المخلفات \\
\hline 38,5 & 77 & 4-تعاون المحليات و الزر اعة لتقديم حل جذرى وشامل للمشكلة \\
\hline 36,5 & 73 & 5-الإز الات المستمرة وتفعيل القانون \\
\hline 24,5 & 49 & 6-حملات قوية ومستمرة فى شتى وسائل الإعلام \\
\hline
\end{tabular}




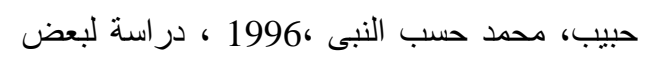

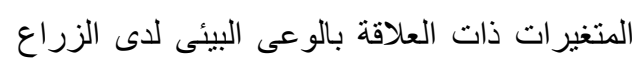

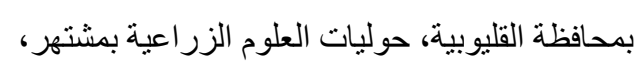
مجلد 34، عدد(2)، ص : 15.

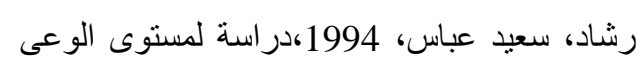

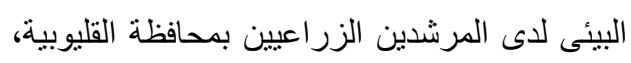

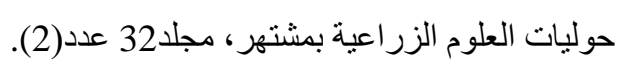

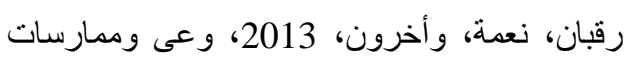

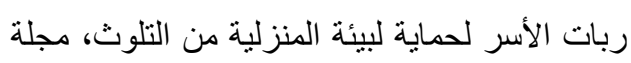

البحوث البيئية والطاقة ، جامعة المنوفية، عدد(2). زهران، يحيى على ، 2015، دعم المكون البيئي فى البى الطئي مهام الإدارة المركزية للإرشاد الزراعي والبيئة، ورشة عمل ، جامعة المنصورة.

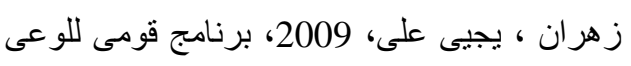

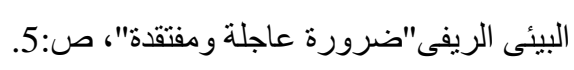

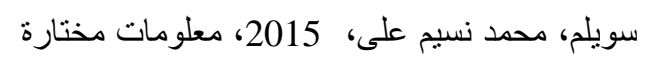

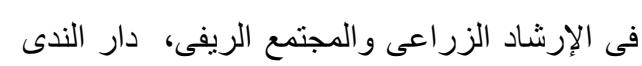
للطباعة، ص:211. شرشر ، عبد الحميد أمين، 2001: 211، تفعيل دور العمل الإرشادى فى حماية البيئة ، أفاق وتحديات الإرشاد فى الئى

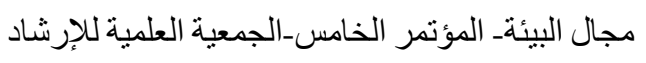
الزر اعى- القاهرة، ص:26. 10. ق قمباز , رحاب السيد أحمد ، 2013، 2013، وعى وممارسات

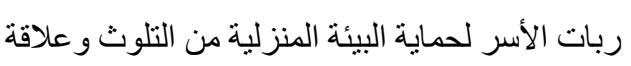

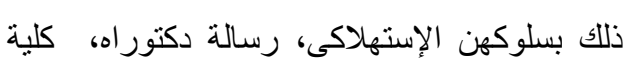

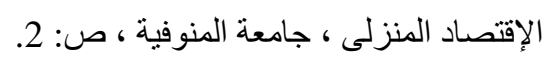

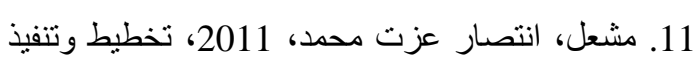
وتقييم برنامج إرشادى لتنمية وعى ربة الأسرة لحماية

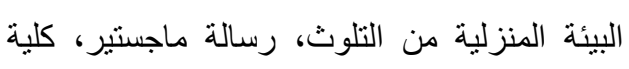
الإقتصاد المنزلى ، جامعة منوفية. .4
التوصيات:

بناءاً على النتائج السابقة يمكن استخلاص التوصيات

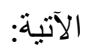

1- ضرورة إهتمام كل من الإعلام ببرامج التوعية

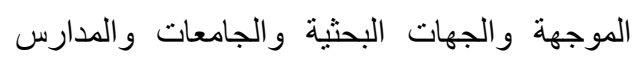

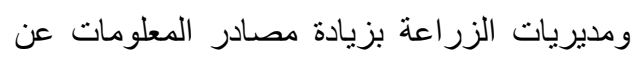

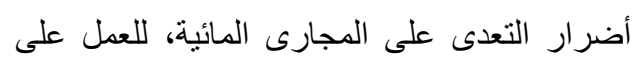
الإرتقاء بالسلوك الإيجابى تجاه المجارى المائية.

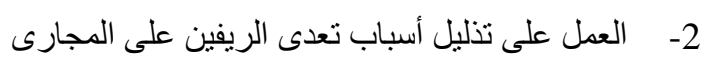

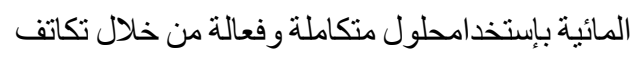

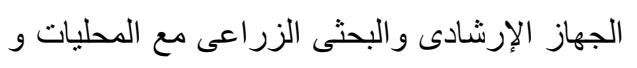

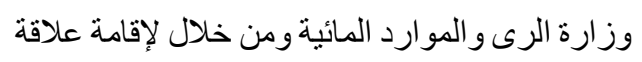

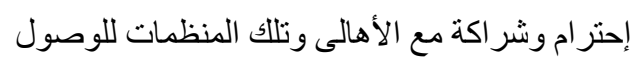

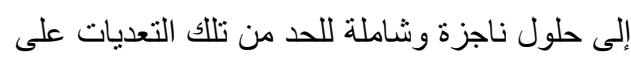
المجارى المائية. 3- يجب تفعيل وتغليظ قوانين التعدى على المجارى

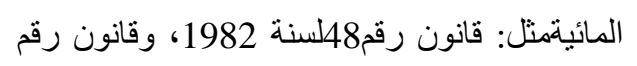
12 لسنة 1984، والإستمرار فى تنفيذ حملات الإز الات بثكل دورى ومستمر. 4- من الضرورى العمل على تثجيع الباحثين فى مجال

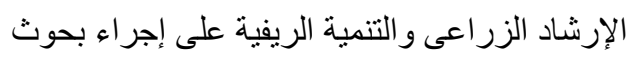

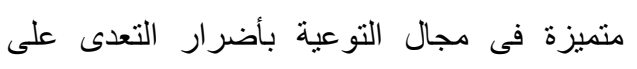

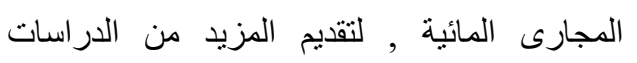
المتخصصة فى هذا المجال .

1. الغنام، عادل فهمى محمود، 2001، الوعى و السلوك

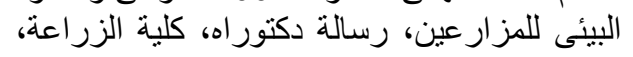
قاليم المجتمع الريفى، جامعة الإسكندرية.

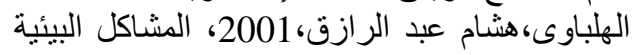

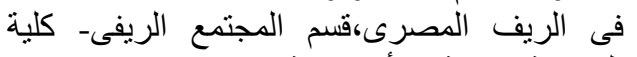
الزراعة-جامعة الأسكندرية, ص:287، 291 .293 


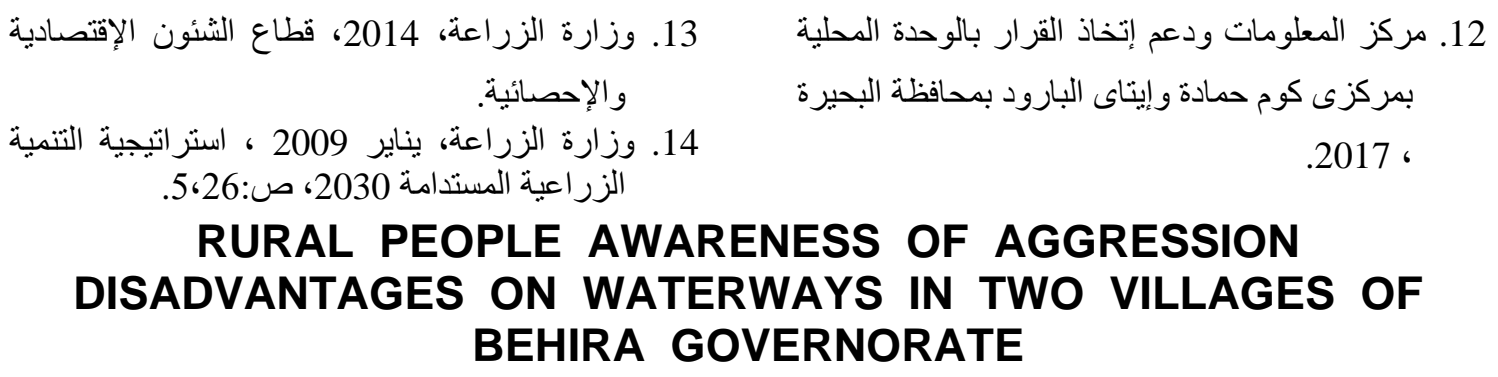

\author{
Amany S. A. El Kholy \\ Researcher, Department of Rural Community Research, Agricultural Extension \& Rural \\ Development Research Institute, Agricultural Research Center,
}

ABSTRACT: The study aimed at identifying the level of rural people awareness level of aggression disadvantages on waterways, and identifying the relationship between the degree of their awareness and some of the social, economic and personal characteristics, also identifying kinds and reasons of their aggressions, in addition to, identifying their obstacles that prevent their awareness. This study was conducted on a random sample of 200 rural people in Behira governorate, Data were collected using personal interview, during March and April 2017, Data were analyzed by using Frequencies, percentages, means, weighted Mean , standard deviation, coefficient Alpha, $T$-test, Anova, Pearson correlation, and multiple linear regressions.

The main finding included:-

1- Awareness regarding aggression disadvantages arranged according to relative importance to: awareness of environmental aggression disadvantages, followed by awareness of health disadvantages, awareness of economic disadvantages, then awareness of social disadvantages, and finally awareness of punitive disadvantages.

2-There is a significant positive correlation between rural people awareness degree of aggression disadvantages on waterways in general and between: years of education, the degree of benefit from information sources, and the degree of leadership, the independent variables collectively explained $80,8 \%$ of the variance in rural people awareness of aggression disadvantages on waterways.

3-There were significant differences between respondents grouped according to sax, participation in development projects, and marriage status.

4-The study identified fourteen kinds of aggression disadvantages, and the reasons of their aggressions were due to: there weren't specified places to collecting garbage and waste, there weren't sanitation network in the village, they are accustomed to those behaviors (cultural belief), And to provide a place for their animals and comfort and Planting, Their proposals were: providing safe and legitimate means to get rid of their garbage and waste, conducting seminars and lectures to increase awareness of aggression disadvantages on waterways, and cleaning it continuously.

It's necessary to activat the role of extensions system for awareness rural people with dangers of aggression disadvantages on waterways, working to remove the causes of aggressions by using effective and complete solutions through the integration of the agricultural extension and research apparatus with municipalities and Irrigation and Water Resources Ministry, and all media by establishing a relationship of respect and partnership with the people and those organizations.

Key words: awareness, disadvantages, aggressions, waterways. 